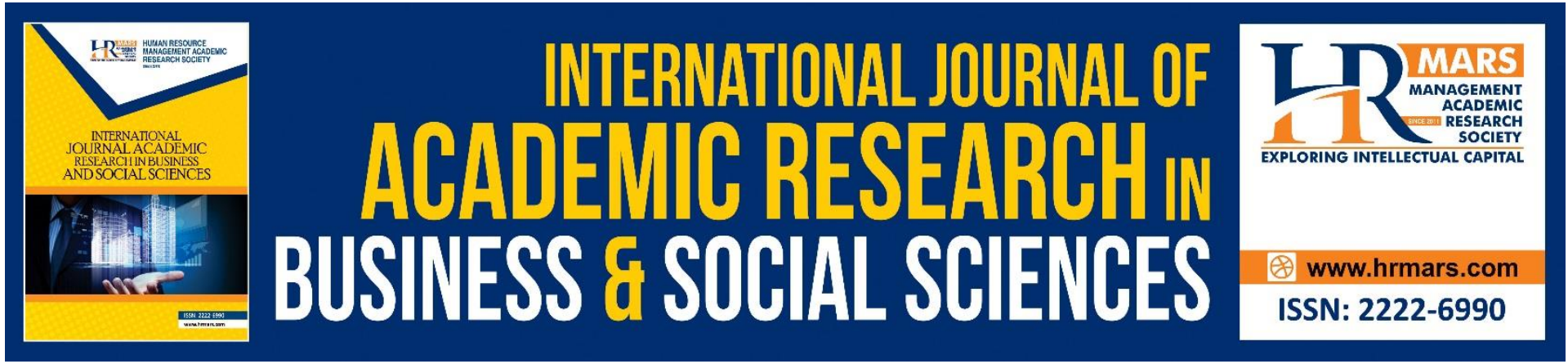

\title{
The Words Used by the Grammarians When Calling into Question \& Challenging the Recitations (Qira'at) and Responding to them
}

Aly Reda Aly Darwish, Mohamed Fathy Mohamed Abdelgelil, Reda Owis Hassan Serour, Ahmad Fauzi Hassan

To Link this Article: http://dx.doi.org/10.6007/IJARBSS/v11-i9/11138

DOI:10.6007/IJARBSS/v11-i9/11138

Received: 09 July 2021, Revised: 10 August 2021, Accepted: 30 August 2021

Published Online: 20 September 2021

In-Text Citation: (Darwish et al., 2021)

To Cite this Article: Darwish, A. R. A., Abdelgelil, M. F. M., Serour, R. O. H., \& Hassan, A. F. (2021). The Words Used by the Grammarians When Calling into Question \& Challenging the Recitations (Qira'at) and Responding to them. International Journal of Academic Research in Business and Social Sciences, 11(9), 1259-1269.

Copyright: (c) 2021 The Author(s)

Published by Human Resource Management Academic Research Society (www.hrmars.com)

This article is published under the Creative Commons Attribution (CC BY 4.0) license. Anyone may reproduce, distribute, translate and create derivative works of this article (for both commercial and non-commercial purposes), subject to full attribution to the original publication and authors. The full terms of this license may be seen at: http://creativecommons.org/licences/by/4.0/legalcode

Vol. 11, No. 9, 2021, Pg. 1259 - 1269

Full Terms \& Conditions of access and use can be found at http://hrmars.com/index.php/pages/detail/publication-ethics 


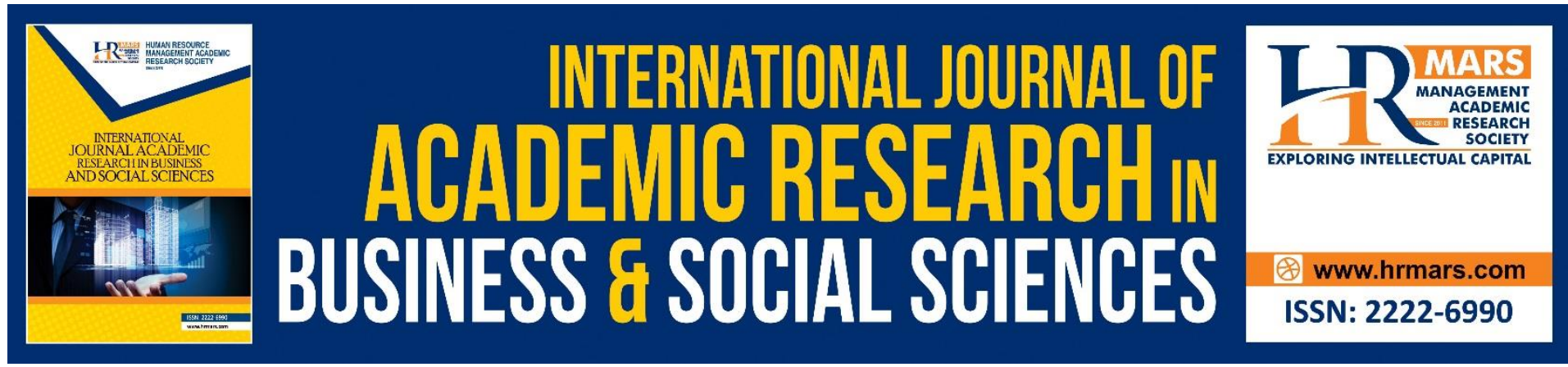

\title{
The Words Used by the Grammarians When Calling into Question \& Challenging the Recitations (Qira'at) and Responding to them
}

\author{
${ }^{1}$ Aly Reda Aly Darwish, ${ }^{1}$ Mohamed Fathy Mohamed Abdelgelil, \\ ${ }^{2}$ Reda Owis Hassan Serour, ${ }^{1}$ Ahmad Fauzi Hassan \\ ${ }^{1}$ Faculty of Islamic Contemporary Studies (FKI), Sultan Zainal Abidin University (UniSZA), \\ 21300, Terengganu, MALAYSIA, ${ }^{2}$ Sultan Abdul Halim Mu'adzam Shah International Islamic \\ University, (UniSHAMS), Malaysia \\ Email: mfathy@unisza.edu.my
}

\begin{abstract}
Grammarians, May Allah have mercy on them; have great merit in directing and winning the Qur'anic recitations (Qira'at). The people of interpretation followed them, but some scholars, despite their merit and righteousness, subjected some recitations (Qira'at) to challenge and rejection. Herein lies the research problem. Which aims to track the words used by the grammarians and interpreters, and then discuss them. The research is based on the analytical method that traces the words of challenge and contestations among scholars, which they directed towards recitations (Qira'at). As this research results in, the Quranic readings are a Sunnah that cannot be challenged and must be accepted. The research also concluded 12 terms used to challenge Quranic recitations (Qira'at). In addition, that these terms may be explicit in the response to the readings, and some of them are not explicit.
\end{abstract}

Keywords: Recitations (Qira'at), Grammarians, Words, Contestation and Challenge, Discussion.

\section{Introduction}

The terms mentioned in the research may open a door to suspicion in terms of challenging the Qur'anic recitations (Qira'at). Undoubtedly, such an appeal is futile. Because the recitations with which the imams of the recitations (Qira'at) recited are proven on the authority of the Prophet, peace be upon him, frequently that is known to the experts. If he proves something, it must be taken into account. Whoever will put his rejection to that, indeed has rejected the Prophet, peace be upon him, and detested what he has recited. This is a dangerous pothole (should be stay away from it) where should not imitate the imams of language and grammar.

\section{Foreword}

Saying that this recitation (Qira'at) according to all grammarians is rejected and has no reason for it except a weak aspect is a statement rejected by predecessors (Qira'at) imams. Because 
(Qira'at) is, Sunnah must be accepted and destines to it. It is not necessary to weaken a (Qira'at) that was proven frequently and regularly on the authority of the imams of (Qira'at) just because it violates a linguistic or grammar rule. Because the consensus of the grammarians is not an argument with the reciters' disagreement with them. In addition, if we assume for the sake of argument that the reciters do not have any expert of grammar, then they are transmitting from someone whose infallibility - peace be upon him - has been proven wrong in his example. Moreover, because the (Qira'at) proved frequently and generally while what was reported by grammarians are individually or personally reports. In addition, the readers are more just, more reliable, and more accurate comparing what grammarians transmit and report, like the one who said the verse of poetry may be he is unknown.

\section{Words used to Challenge the Recitations (Qira'at)}

Scholars, May Allah have mercy on them; have several words in refuting the readings and challenging them, which will appear in the following points:

\section{Wrong}

Declaring a Qira'at is also a reason to be against of reciters. Accusing the reciters of delusion and error with its authenticity and frequency of transmission from the imams (Qira'at). Like the saying of al-Zujjaj as Almighty Allah says,

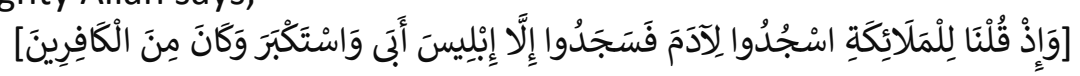

And [mention] when We said to the angels, "Prostrate before Adam"; so they prostrated, except for Iblees. He refused and was arrogant and became of the disbelievers. [Al-Baqarah:

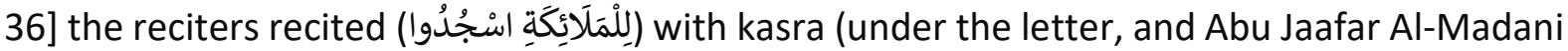

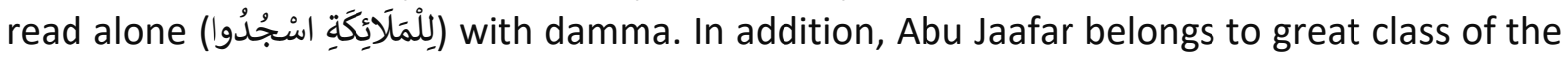
people of Medina and one of greatest specialist in Qira'at, but he is wrong in this letter. Because the word (مَلَائكِةِ) is in the state of (الخفضِ), it is not permissible to read it in a state of (تاء التأنيث) (تمع). However, he likened the reading it with kasra alif al-wasl, same as a grammar rule as you begin (the sentence or word) to say: (أسجدوانع). The Qur'an should not be read with illusions other than the right one. (Al-Zujjaj, 1988, 2/618). Now we see that the correct direction for this Qira'at. He intended to make a stop (الوقف) on a (التاء ساكنة) and then read it with damma following the damma of the letter (الجيم). In addition, this is from the procedure of connecting the course of the (الوقف). Similarly, what was narrated from a woman who saw

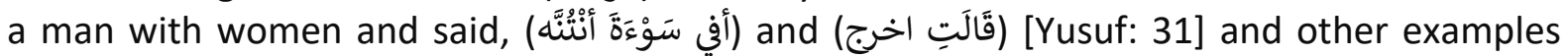
related to this chapter. And directing this repetitive Qira'at is more important than its composition, and also for the majesty of its reciter, Abu Jaafar Yazid bin Al-Qa'qa', Sheikh of Nafi', the sheikh of Medina, and their biography is well known (Al-Samin Al-Halabi, 2016, 1/171).

Illusion

Other reason for reciters offense, delusion is also a grammatical rule. As Allah, the Most High, says,

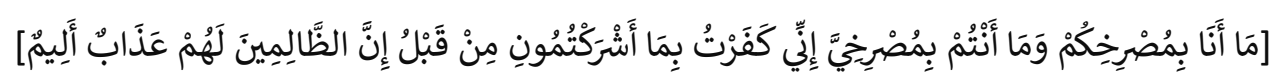

I cannot be called to your aid, nor can you be called to my aid. Indeed, I deny your association of me [with Allah] before. Indeed, for the wrongdoers is a painful punishment [Ibrahim: 22]. Al-Farra' said that Al-A'mash and Yahya bin Wasabi read the letter (الياء) in the state of (الخفض)." Then Al-Farra' said, "Among the illusion of the reciters is Yahya's class, for few of

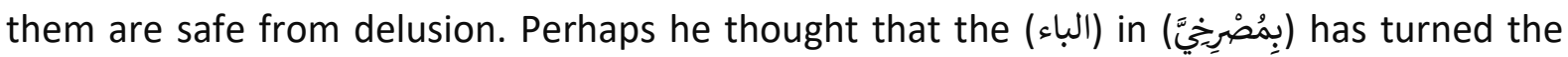


word in the state of (الخفض) completely, but the (الياء من المتكلم) is out of that. (Al-Zujjaj, 1988, 3/98).

\section{Rejecting Qira'at}

Rejecting a Qira'at is also a reason to be against of reciters based on linguistic rule. Moreover, accusing the narrators of mistakenly reporting. Example is what Almighty Allah is saying,

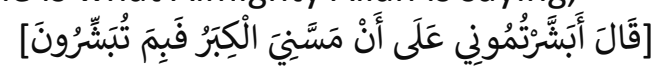

He said, "Do you give me good news when old age has come upon me? What then do you give me good news of?" (Al-Hijr 54). Abu Hatim accused the Qira'at of Nafi' an error (تُبَّنَّرُونِ as he read it with (بكسر النون مخففة), and he (Abu Hatim) said (This is in poetry by necessity). It was narrated on the authority of Abu Amr bin Al-Ala - may Allah have mercy on him - that he said, "reading (كسر النون) is a melody. He also said, "And this reading has been challenged by a group because of the distance and dimension of its phonation and vocalization in Arabic. Because deleting the (النون) with (الياء) does not sounds good, except in poetry. Moreover, if it is possible to delete the first (النون), you will delete the sign of (الرنع), because it is of any neither (جازم) nor (ناصب), and to read the (النون) with kasra, which is the sign of (النعح), is disgraceful. However, it deserves (الفتح) and the choice is (تخفيف+الفتح). Because it is the reason of speech and the rank of syntax, and because it is the most reciters follow. (Al-Sameen Al-Halabi, 2016, 7/165). Makki said the same. (Makki, 1405, 2/31; Al-Nahass, 1409, 2/241), and the Qira'at is correct and valid while it is not allowed to reject it.

\section{Error}

This is also a reason to be against of reciters based on linguistic rule. In addition, accusing the narrators of mistakenly reporting. This verse for example,

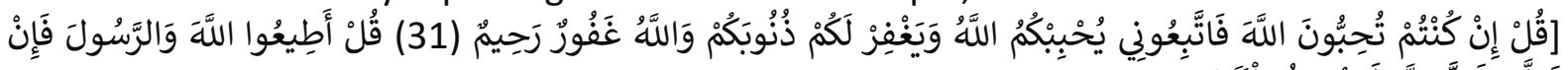

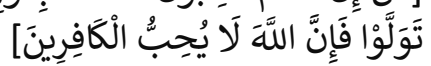

Say, [O Muhammad], "If you should love Allah, then follow me, [so] Allah will love you and forgive you your sins. And Allah is Forgiving and Merciful." (31) Say, "Obey Allah and the Messenger." But if they turn away - then indeed, Allah does not like the disbelievers. [AlImran: 31]. Zujjaj said (وَيَغْفِز لَكْمْ) Reading by (بإظهار الراء مع اللام). Some of the grammarians claimed that the (الراء) is mixed in the (النامنَفْفر لَكُمْم) so it is permissible to read and this is a serious and grave mistake and I do not know if anyone who has read it other than Abu Amr ibn al-Ala. In addition, I think those who narrated on the authority of Abu Amr that the (الراء) in the (اللام) are wrong. Indeed, it is a blunder in Arabic; because the (النون) and the (اللام) is mixed with, the (الراء) like your saying, (هل رأيت) ، (أرن رأيت) and do not mix the (الراء) in the

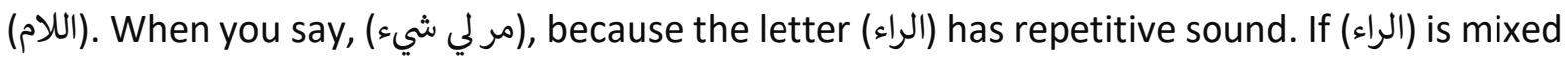
in (اللام) the repetitive quality will be vanished. This is the consensus of grammarians who are trusted with their knowledge" (Al-Farra', 1988, 1/431).

The Tune and Melody, which is not Allowed

Almighty Allah says,

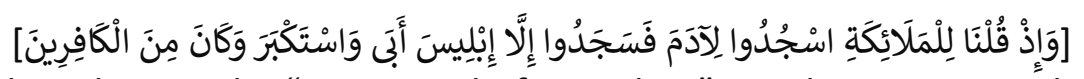

And [mention] when We said to the angels, "Prostrate before Adam"; so they prostrated, except for Iblis. He refused and was arrogant and became of the disbelievers. [Al-Baqarah: 36]. Abu Jaafar Al-Madani read alone (لِلْمَلَئَكَة اسْجُدُوا) with damma. The Zujjaj accused him of a mistake in it and the al-Farsi counted him wrong. I have shown directing this correct Qira'at in the term (wrong). And also in what Almighty Allah says, 


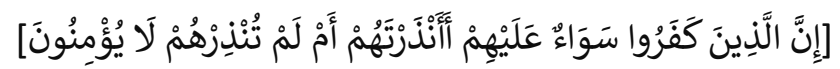
Indeed, those who disbelieve - it is all the same for them whether you warn them or do not warn them - they will not believe. [Al-Baqarah. 6].

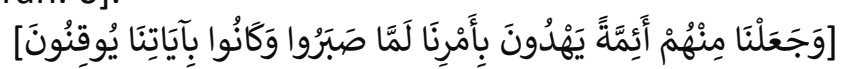

And We made from among them leaders guiding by Our command when they were patient and [when] they were certain of Our signs. [As-Sajdah: 24] Nafi', Ibn Katheer, and Abu Amr recited the second (الهمزة) of the two (الهمزة) that occur in a word with ease and softness

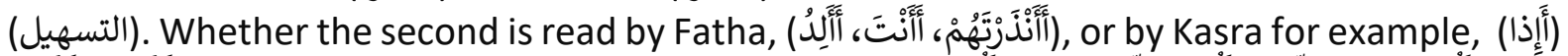

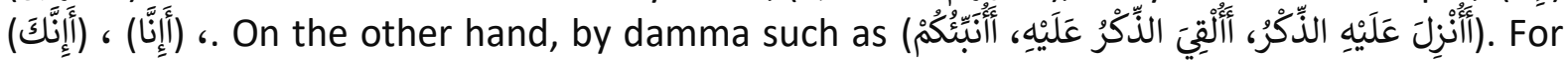
Hisham there is two ways to read it if the second (الهمزة) read with Fatha. One of them is to read it with ease and softness (التسهيل) and second is to read both (الهمزة), and to read both (الهمزة) if it is read with kasra or damma. Narrators differed from Imam Warsh in how to change the second Hamza when it is read with Fatha. The Egyptians narrated that (الهمزة) replaced by (ألف). Narrators from Baghdad narrated that it will be read with softness and the tone should be between the tone of damma and kasra. So, for Imam Warsh there is only way if the second (الهمزة) read with damma and kasra. There are two ways if it is read with Fatha, to change it

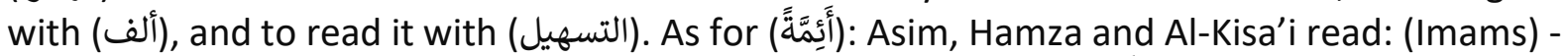

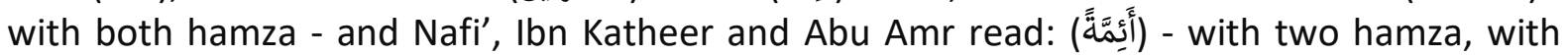
(التسهيل) without adding (ألف). In addition, he narrated on the authority of the Kufic scholars and Ibn Amir that to read it (تخفيف) without inserting a (ألف) between both hamza except that Hisham inserted a (ألف) between them. And Ibn Katheer, Abu Amr, and Nafi' also recited (أخفيف) (أَيَّة) - with (ياء) through the chain (الطيبة) (Al-Qadi, 1992, 1/84-88; Ibn Al-Jazari, 2009, 1/378).

Al-Zamakhshari attributed what narrated by Imam Warsh through the Egyptians, replacing that (الهمزة) replaced by (ألف), it is just pure melody. He said, "Because it leads to the combination of two consonant who are not apart. And because the (تخفيف) of such a (الهمزة) is between the two tones." (Al-Samin Al-Halabi, 2016: 1/110). And (Sibawayh) said, "And if two (الهمزة) meet in a word, then the it is better to turn the second into a soft letter (تخفيف),

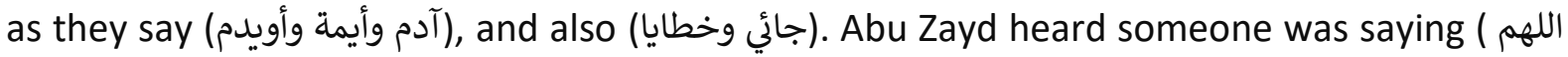
(اغهر لي خطائي (أهزة) he said, Abu al-Samh and Raddad (his cousin) has read it with it is irregular and exceptional Qira'at. In the Kufic recitation (أئمة) (al-Tawbah: 12) “Asim, Hamzah and al-Kisa'i are among reciters of Kufa recited this. Ibn Amir al-Yahsibi recited this among the reciters of Syria. The (الهمزة) is an independent letter. Because its articulation point is far. As it is a tone and accent in the chest that comes out after toiling hard, so it was difficult for them to speak it. Because it is like retching. Therefore, the people of Hijaz tended to read it with (تخفيف). (Ibn Ya'ish, 2002, 5/279). Al-Zujjaj responded to reading both Hamzah (التحقيق) where he says, ".... As for the grammarians, they do not permit the meeting of the two (الهمزة) here,

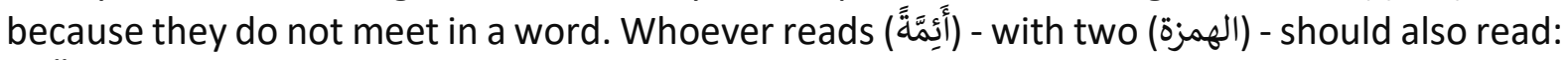
(ايابني أدم)" (Al-Zujjaj, 1988, 2/ 434). In addition, the reading two Hamzah (التحقيق) is not commensurate with the school of Basra. Ibn Jinni said, "The two (الهمزة) do not meet in one word unless they are two real letters of the word: (سأل، وسئال)... but their meeting in one word, other than to be a real word is a melody except what we have mentioned irregular unusual examples such as (خطائي) and related to this chapter." (Ibn Jinni, 1988, 3 / 143). AlZamakhshari attributed what narrated by Imam Warsh through the Egyptians, replacing that (الهمزة), it is just pure melody. He said, "Because it leads to the combination of two consonant who are not apart. And because the (تخفيف) of such a (الهمزة) is between the two tones." We believe that this statement from Al-Zamakhshari is not correct because this recitation has been proven as a frequent Qira'at on the authority of the imams of recitation 
and Qira'at. There is much work for the reciters about this verse, the detail is widespread, and it is proven according to some Arabs from Tamim. (Al-Sameen Al-Halabi, 2016, 1/110).

The Qira'at is not Legal and Permitted at all

This is also a reason to be against of reciters based on linguistic rule and accusing reciters of not being accurate and precise in Qira'at. As the Almighty's saying,

$$
\text { [إِنْ تُبْدُوا الصَّدَقَاتِ فَنْعِمَّاِ }
$$

If you disclose your charitable expenditures, they are good; [Al-Baqarah: 271] The Almighty is

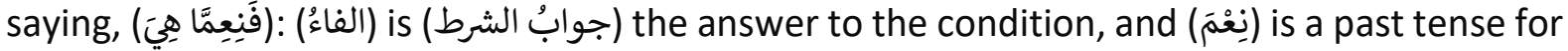
praising someone or something, the opposite of (بئس). In addition, its ruling is in the nonaction. Nevertheless, Ibn Amir, Hamza, and Al-Kisa'i read here and in the (النساء) (فَنَعَمَاء) with Fatha on (العين) and kasra on (العين). This is based on the original, because the original is based

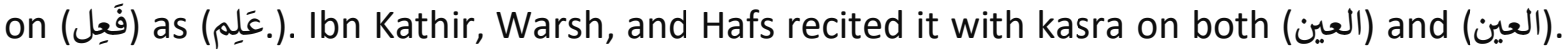
The kasra on (العين) is only following the kasra on (العين), which is the dialect of Huzail tribe. It is possible to read the (العين) (العين) (العن) origin ith kasra, as the consonant. When after that (العين) (مان) occurred and the (ميم) of (العين) was mixed in it, the (نِعَ) was read with kasra because of two consonant letters combined. Abu Amr, Qalun and Shu 'bah read it with kasra on the (العين) and concealing the movement of the (العين). Reading it with consonant condition was also narrated from them. Abu Obeid adopted it also. Moreover, he narrated it in the language of the Prophet - peace be upon him - in the manner of his saying,

"Amr! Sound (legitimately acquired) wealth is very excellent for a righteous man!'" (Bukhari, 1989, H: 299, 1/112). Al-Zujjaj said, "I do not think the companions of the hadith have narrated this accurately and precisely. Nor this Qira'at is permissible at all, because it contains a combination of two consonants without a vowel (مد ولين)." while the majority's opinion is the embezzlement over consonant (الإسكان). Rather, some of them made it an illusion of narrators on the authority of Abu Amr. In addition, those who refused it like Mubarrad, Zujjaj and the al-Farsi said, because in it there is a combination of two consonants, which are not in their limit. Al-Mubarrad said, "No one is able to pronounce it. Rather, someone wants to combine two consonants, so he does it reading it with short vowel (حركة) without feeling it." Farsi said. "Perhaps Abu Amr read it with (إخفاء), but the narrator misunderstood for consonant." Moreover, it has been cleared that the kasra on (النون) is only following the kasra on (العين), which is the dialect of Huzail tribe. While reading with (الإسكان) (الن (ال) was narrated with the chain of transmission related to the Prophet - may God's prayers and peace be upon him - and the hadith is authentic and Sahih as have explained. Abu Obeid also adopted it. It is not permissible to reject the Qira'at. (AI-Sameen Al-Halabi, 2016, 2/208-209).

This is a Huge Mistake (Blunder)

This is also a reason to be against of reciters based on linguistic rule and accusing the readers of lacking control over the narration as the Almighty says,

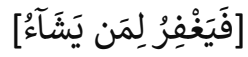

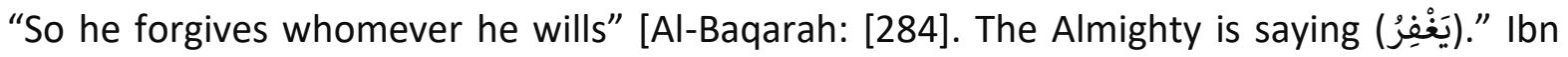

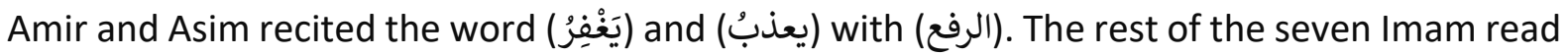

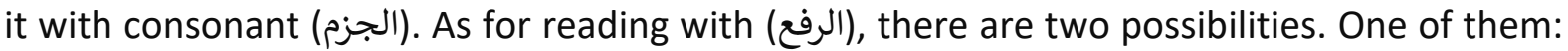

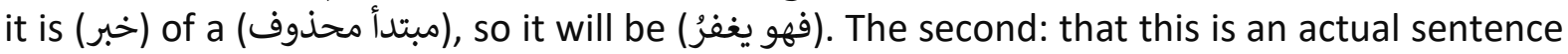
of a verb and a subject that is conjoined to what has mentioned before it. As for the consonant (الجزم), it is because of conjunction to (الجزاء المجزوم). In addition, Abu Amr read by combining 
the (الراء) in the (اللام) and the rest of reciters read it with (إلظهار). Ibn Kathir read the (الباء) before (إظهار) with a difference of opinion from him. While Warsh from Nafi' and the rest have read it with (الإدغام). Some people have challenged the recitation of Abu Amr because inserting the (الراء) into the (اللام) is weak for them. Al-Zamakhshari said, "If you say, How to read a (الجازم)? I say, read the (الظهار) and let the (الباء) to be combined. In addition, combining the (الراءم) with (اللام) it is a grave mistake. Moreover, the narrator on the authority of Abu Amr is wrong twice. Because it is composed and attributed to the most knowledgeable person of Arabic language who cannot allow a great ignorance. The reason in these narrations and reports is to lack of accuracy and control of narrators. The reason for lack of control is the lacking of expertise (الدراية). Only the grammarians can have such control. We see this opinion from Al-Zamakhshari as unsatisfactory. The reciters are concerned in this regard, because they have learned letter after letter face to face from their sheikhs, so how can their control decrease? It is something that is perceived by the sense of auditory. The thing that prevents the (الراء) from being mixed with the (النام) and the (النون) is the repetitive quality of the letter (الراء) and its strength, and the strongest does not mix with the weaker. This is the doctrine of the Basra: Imam al-Khalil, Sibawayh and those who followed them. Al-Farra", Al-Kisa'i, Ya'qub Al-Hadrami, and top of them Abu Amr permitted this. Moreover, his opinion is not acknowledged that this narration is wrong in his opinion". How can it be said that the narrator on the authority of Abu Amr is twice wrong? Among his narrators is the Yazidi who is a great imam of grammar and language. He was contesting Al-Kisa'i. It is a well-known story among the people in this regard. (Al-Sameen Al-Halabi, 2016, 2/687).

Impossible

As an-Nahass said related to what Almighty Allah says,

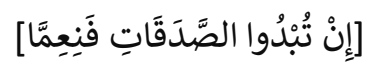

If you disclose your charitable expenditures, they are good; [Al-Baqarah: 271] - "As for what was narrated on the authority of Abu Amr and Nafi' reading (العين) consonantly, it is impossible." (Al-Nahass, 1989, 1/338), and the researcher has explained this Qira'at well, indicating its correctness in the term: (this reading is not permissible at all).

Melody that it is not Permissible to Recite

This is also a reason to be against of reciters based on grammatical rule. Its example is what almighty Allah has mentioned,

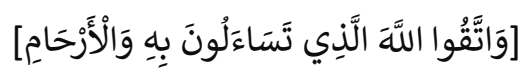

And fear Allah, through whom you ask one another, and the wombs." [An-Nisa: 1]. Hamza recited, (الَََّْْحام) with kasra on (الميم), and the rest of reciters read it with Fatha. It is the reading of one of the seven reciters - Hamza al-Zayyat - And the reading of Ibrahim Al-Nakha'i, Qatadah, Yahya bin Wathab, Talha bin Masraf and Al-Amash. Also the narration of Al-Isfahani and Al-Halabi on the authority of Abd Al-Warith. The word (الَََْْحَامِم) is read with Fatha and kasra. And the proof for the one who read it with Fatha it is that it is connected to word (الآَّ) the Most High, and he meant to say, (واتقوا الأرحام: لا تقطعوها). This is the aspect of recitation according to the doctrine of the Basra, and as for the Kufic doctrine, they permitted to read it with kasra and argued to the reader that there is hidden (الخافض) and they inferred that (Al-

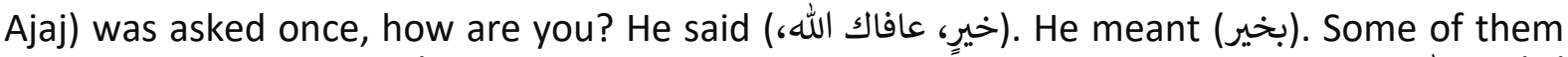

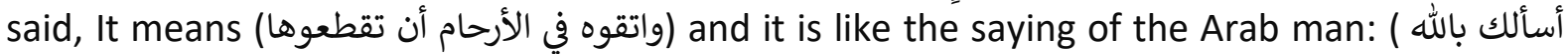
(Al-Anbari, 2004, 2/381; and Ibn Al-Jazari, 2009, 2/247). In the reading of Hamza, it is read as connected (عطف) to the pronoun in the word (به) with kasra without repeating the 
(الجارّ). This is not acceptable to most of the grammarians and the majority of Basri grammarians turned down it taking care of the rule which is conjunction of noun with pronoun without repeating the (الجارّ) and seven great masters of Qira'at has rejected this Qira'at and weakening it, rather they called it an error it, and forbid reciting it. The first to open the door to challenge this Qira'at is Imam Sibawayh - may Allah have mercy on him - Ibn Atiyyah says, "This recitation according to the great grammarians of Basra is not permissible... As for Sibawayh, it is reprehensible to him." (Shukri, 1987, 3/185). In addition, if we want accuracy, we say, Al-Khalil bin Ahmad was the first to open the door to challenge this Qira'at, and Sibawayh took it from him and this is Sibawayh's text; it is disgraceful for the (الظاهر) to associate with the (المضمر المجرور), for example: (مررت بك بزيد)... As for associating it, it is not permissible, because it is not good to associate in (فورئ) (فعلت وفعلتم) except (بأنت وأنتم), and this is the opinion of the Khalil. However, it may be permissible in poetry to combine that between the (الظاهر) and the (المضمر) in the (المرفوع) and the (المجرور) if the poet is forced to; it is permissible to say (جاز قمت أنت وزيد). But is not permissible (مررت بكروبك أنت وزيد) because the verb dispenses with the subject and can manage without a subject but the (المضاف) does not dispense with the (المضاف إليه), because it is like the intention." (Sibawayh, 1988, 1/391). Ibn Atiyyah responded to this Qira'at by saying: "And this reading comes to me in the aspect of the meaning with two ways.

It is not (even a) Qira'at

Being against the reciters of Qira'at from doctrine of the Basra and accuses the reciters of Qira'at of distorting such as what Almighty Allah has said,

[فَقَاتِلْوا أَيْمََّة الْكُفْرِ]

"So fight the chiefs of unbelievers" [At-Tawbah: 12]. Nafi', Ibn Katheer, and Abu Amr recited

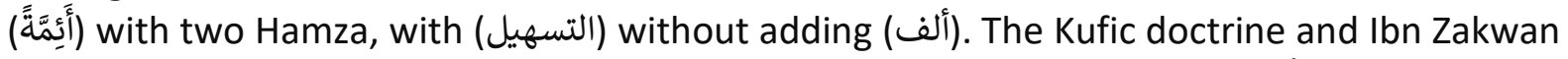
on the authority of Ibn Amir that to read it (تخفيف) without inserting a (ألف) between both Hamza except that Hisham inserted a (ألف) between them. This is what is most famous among great seven imam of Qira'at. It was reported on the authority of Nafi' and those who followed him that they replace the second Hamza with an explicit (الياء). And that it has been transmitted from Nafi' (المدُّ) between them, i.e. between the Hamza and the (الياء). (الياء). As for the reading (التحقيق) with the tone between two (الحركة), it was weakened by a group of grammarians such as Abu Ali al-Farsi and his followers. In addition, there are reciters of Qira'at among them who weakened the reading with (التحقيق) having his narration as a proof from him. Moreover, Qira'at has been recited to his companions as well as among them are those who denied reading it with (التسهيل), so they did not recite it by this way but they recited the (ياء) with a slight tone of kasra. As for the recitation of (ياء), it is the one that was accepted by the al-Farsi and this group, because the pronunciation of the two (الهمزة) in one word is heavy, and reading (الهمزة) with the tone between two (الحركة) is much slighter and easier. While AlZamakhshari read it with explicit (ياء) as a melody and reading two (الهمزة) with is not

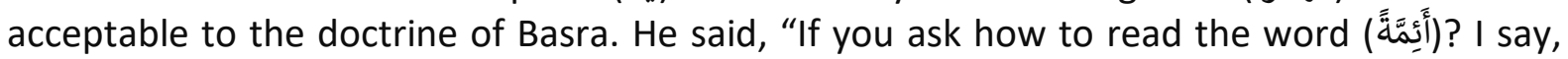
with a (الهمزة) after it another (الهمزة) which sounds between the pronunciation of the (الهمزة) (الهمزة) and the (الهمزة) (الهزة) (التحقيق) Reading the two is a well-known Qira'at, although it is not accepted by the doctrine of Basra. In addition, reading with clear (ياء), it is not permissible for it to be, and whoever recites it is a corrupted and distorted melody. We see that it is not surprising that this is what it used to compose to the reciters, and how it is a melody as the head of the Basri grammarians, Abu Amr bin Al-Ala, the reciter of Mecca Ibn Katheer, and the reciter of Madinah Nafi' have recited it? We see: that there is nothing to take revenge on Al- 
Zamakhshari, for he said that it is not acceptable to the doctrine of Basra. This does not mean that he does not accept it; the purpose of the chapter is that it was transmitted from others. As for reading with clear (ياء), his is excuse is acceptable because, as I have presented to you, it is well known among the reciters that to read it (التسهيلُ بين بين) not just to make changes (الإبدال), to the extent that Al-Shatibi made this the doctrine of the grammarians, not the reciters of Qira'at. Al-Zamakhshari chose the doctrine of the reciters, not the doctrine of the grammarians in this word. Abu al-Baqa' rejected the reading (التسهيلِ بينَ بينَ) "It is not permissible here to read the (الهمزة) with (التسهيلِ بينَ بينَ) same as the hamza (أنئل), because the kasra here is passed on and there is the original. The meme is originally. if the second (الهمزة) [here] read with (تخفيف) according to the analogy and compare it with that, it would be turned into an (ألف) due to the Fatha on the letter before it, but it is left to be read with the (الحركة) of (الميم) in the original. We see that his saying (transported) does not make any sense because the transmission here is necessary. Therefore, it is like the original. Moreover his saying, "And if it is read with (تخفيف) according to the analogy.... to the end" is also not useful.

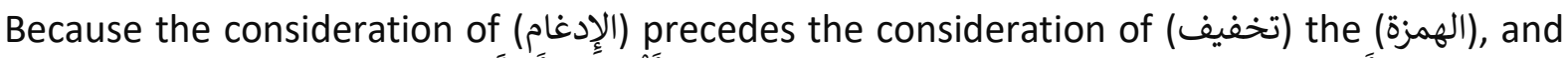

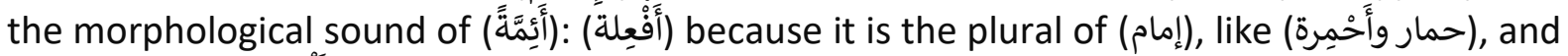

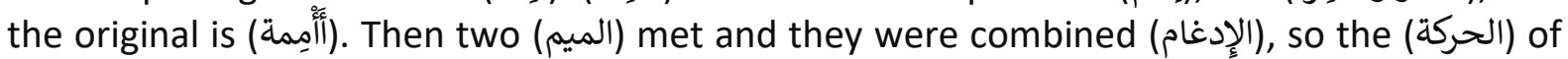
the first (الميم) was transmitted to the consonant letter before it which is the second (الهمزة). This led to the meeting of two (الهمزة), the second of which is read with kasra: grammarians of

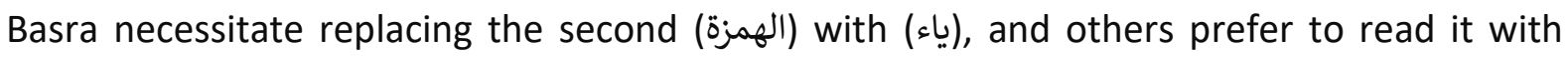

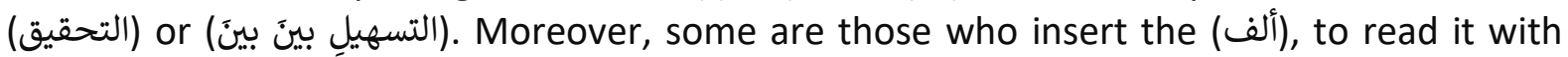
until they differentiates between the two (الهمفيف). It is better than that this should be

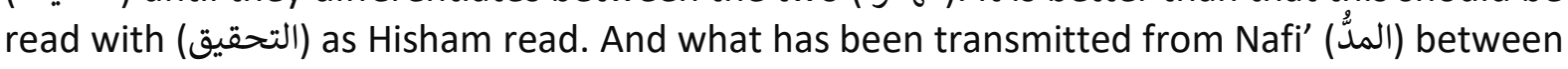
them, i.e. between the Hamza and the (تخفيف) then this is an exaggeration in (الياء) (لمفيق) (Al-Samin Al-Halabi, 2016, 6/23-25), Al-Zujjaj responded to reading both Hamzah (التحقيق) where he says, ".... As for the grammarians, they do not permit the meeting of the two (الهمزة) here, because they do not meet in a word. Whoever reads (الهمزة) (الئَيَّة) - with twould also read: (يابني أدم)" (Al-Zujjaj, 1988, 2/ 434). In addition, the reading two Hamzah (التحقيق) is not commensurate with the school of Basra. Ibn Jinni said, "The two (الهمزة) do not meet in one word unless they are two real letters of the word: (سأل، وسئال)... but their meeting in one word, other than to be a real word is a melody except what we have mentioned irregular unusual examples such as (خطائئ) and related to this chapter." (Ibn Jinni, 1988, 3 / 143).

(This Qira'at is) Not Permissible

This is also a reason to be against of reciters based on grammatical rule. As Almight Allah said,

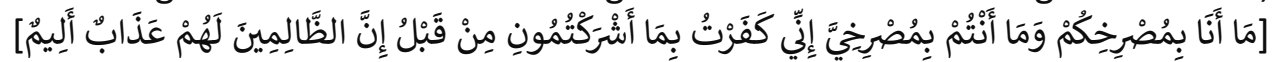
I cannot be called to your aid, nor can you be called to my aid. Indeed, I deny your association of me [with Allah] before. Indeed, for the wrongdoers is a painful punishment [lbrahim: 22].

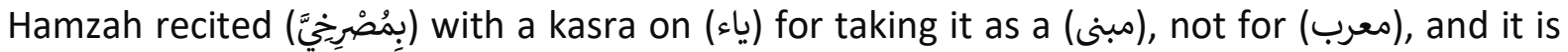
similar to the pronoun ha' (هاء الضمير) in that each of them is a pronoun consists on a letter. The (هاء الضمير) connects to (الواو) if it is read with damma, and (الضياء) if it is read with kasra, and it is read with kasra after the kasra and the (اليمير) (الساءكنة), so it is read with kasra as (الهاء)) is read with kasra in word (عليْي) Which is the dialect of Bani Yarbu' (sub-tribe from Tamim). This was stipulated by Qutrub and approved by him, Al-Farra', and the imam of language, grammar and Qira'at, Abu Amr bin Al-Ala. Abu al-Qasim ibn Ma'an the grammarian said, "It (Qira'at) is right and does not count the words of Zamakhshari and others who have weakness, or declared it as an error or mistake. It is a genuine Qira'at in which have met the three pillars. 
Yahya bin wassaabi and Suleiman bin Mehran al-a'mash and Humran bin A'yan and a group of followers." (Ibn al-Jazari, 2000, 2/298; al-Qurtubi, 1964, 9/357). The grammarians attacked this Qira'at with a violent attack, so look at their following statements: Al-Farra' said, "Perhaps it is from the illusion of the reciters from Yahya's class, for few of them are safe from illusion." He also said, "The recitation of Hamzah is a delusion from him, and few of them are safe from a mistake." Al-Zujjaj mentioned, "This Qira'at, according to all grammarians, is bogus and reprehensible, and there is no reason for it but a weak one." Abu Ubaid said, "We have watched those making mistakes, thinking that the (الياء) would be read with kasra for what comes after it." Al-Akhfash quoted, "I never heard this from any of the Arabs, nor from grammarians. An-Nahass said, this has become a consensus, and it is not permissible for the Book of Allah to be carried against perversions (Al-Samin Al-Halabi, 2016, 7/88; Shukri, 1987, $6 / 428)$.

\section{Not Permitted in Arabic}

This is also a reason to be against of Qira'at based on grammatical rule and the apparent meaning. Such as the saying of Al-Farra' in the recitation of Ibn Amir as the Almighty Allah says, (كُنْ فَيَكُونُ) where it occurred except for the saying (كُنْ فَيَكُونُ الْحَقُّ مِنْ رَبِّكَ) (al- Imran, 59-

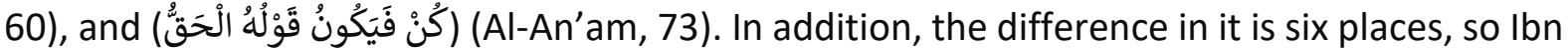
Amir read the (نصب) (النون) in the six places, and Al-Kisa'i agreed with him in An-Nahl and Yaseen (النحل ويس). The rest of reciters read with the (النحف) in both of them as others, (and

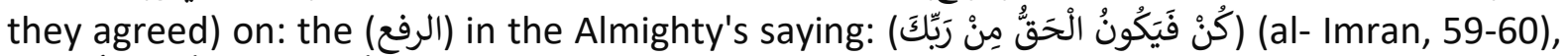
and (كُنْ فَيَكُونُ قَوَلْهُ الْحَقُّ) (Al An'am, 73). (Ibn Al-Jazari, 2009, 2/221).

\section{Conclusion}

After we went through this research, we concluded several results, the most important of which are:

1. The all Qur'anic Qira'at are part of Sunnah, and it is not permissible to challenge or detract from them, even if we see the challenge from scholars, whether they are grammarians, exegetes or others.

2. The research concluded that there are 12 terms used to challenge the Quranic Qira'at.

3. The terms used by scholars in refuting the Qira'at, some of them are explicit and some are not. However, both of them are not acceptable because there is deny for Qira'at, and this is not permissible.

4. The number of words mentioned in the research does not necessarily mean that they are the only ones that were used by the scholars, as there may be other words that were not included in the research and this depends on further research and investigation.

\section{References}

Al-Quraan Al-Karim.

Abdelgelil, M. F. M. (2020). Grammarians' Critique of Qur'anic Qira'at. International Journal of Academic Research in Business and Social Sciences, 10(11), 1225-1231.

Abdelgelil, M. F. M. (2020). Solving the Quranic Issues with Quranic Qira'at, International Journal of Academic Research in Business and Social Sciences, 10(12), 36-42.

Abdelgelil, M. F. M., Al-Janayni, M. U., Baru, R., Hamzah, M. S., Razali, M. A. T. M., \& Ismail, F. Z. (2018). Tawjih Al-Qira'at Based on Inscription, Language, and Unusual Modes of Recitation According to Ibn Zanjalah. International Journal of Academic Research in Business and Social Sciences, 8(10), 362-370. 
Abdelgelil, M. F. M., Daud, N. B., Omar, N. B., Ismail, F. Z. B., \& Wahab, A. H. B. A. (2018). Taujeeh Al-Qira'at Using Qur'an, Hadith and Poetry according to Ibn Zanjalah. International Journal of Academic Research in Business and Social Sciences, 8(10), 371-379.

Abdelgelil, M. F. M., Musolin, M. H., Serour, R. O. H., Abdullah, M. S., \& Noor, M. N. M. (2018). Law and Moral Values in the Holy Quran. International Journal of Academic Research in Business and Social Sciences, 8(11), 445-451.

Abdelgelil, M. F. M., Hassan, A., Yusof, N. H., Idris, M. F. H., Hasan, A. F., \& Ramadan, A. A. (2020). Defending the Quran in the Study of Tawjeeh Al-Qira'at, International Journal of Management, 11(10), pp. 101-104.

Abdelgelil, M. F. M., Razali, M. A., Hassan, A., Hasan, A. F., Idris, M. F. H., \& Masoud, A. S. (2020). Quranic Inimitability in Quranic Qiraat, International Journal of Management, 11(10), pp. 117-121.

Al-Anbari, A. (2004). Al-insaaf fi masail ilkhilaaf bainam- nahwiyyen al basriyyen wal kofiyyen. Beirut: Maktaba al-'asariyyah.

Al-Bukhari, M. (1987). Sahih Bukhari. Investigation: Mustafa Dib Al-Bagha. Damascus: Dar AlYamamah.

Al-Nahas, A. (1989). Ma'anial quran. Investigation: Al-Sabouni. Makkah Al-Mukarramah: jami'ah Umm Al-Qura.

Al-Qurtubi, M. (1964). Al-jami' li-ahkaam il quranil karim. Cairo: darul kutub al-misriyyah.

As-sameen Halabi, A. (2016). Durrul mason fi ‘uloomil kitabil maknoon. Investigation: Ahmed Muhammad Al-Kharrat. Damascus: Dar Al-Qalam.

Furra', Y. (1988). Ma'aniyal quran. Investigation: Ahmed Youssef Al-Najati, Muhammad Ali AlNajjar, and Abdel-Fattah Ismail. Cairo: al-hayyat almisriah al-'ammah lil-kitab.

Ibn Al-Jazari, M. (2000). Munjidul Muqrieen wa Murshidut- talibeen. Beirut: darul kutub al'ilmiyyah.

Ibn Al-Jazari, M. (2009). An-nashar fi qiraat al-A'shr. Investigation: Ali Muhammad Al-Dabaa. Beirut: darul kutub al-ilmiyyah.

Ibn Jinni, O. (1986). Al- khasais. Investigation: Muhammad Ali Al-Najjar. Cairo: al-hayyat almisriah al-'ammah lil-kitab.

Ibn Jinni, O. (1999). almuhtasib fi tabyin wujuh shawazul qira'at wal'iidah enha. Investigation: Ali Najdi Nasif. Cairo: wizarat al'awqaf almajlis al'aelaa lilshuyuwn al'iislamiyyah.

Ibn Ya'ish, A. (2002). Sharah al-mufassal lil Zamakhshari. Beirut: darul kutub al-ilmiyyah.

Makki, M. (2005). TMushkil 'iraabul Qur'an. Investigation: Hatem Salih Al-Dhamin. Beirut: muassasah Al-Resala.

Shukry, A. (1987). Al- Qira'at fil Tafsir al-bahrul Muhet l-ibn Hayyan Andalusi. Master Thesis. Medina: The Islamic University.

Sibawayh, A. (1988). Al-Kitab. Investigation: Abdel Salam Haroun. Cairo: Maktabah Al-Khanji. Zujajj, I. (1988). Ma'aamiyal Quran wa 'iraabihi. Investigation: Abdul Jalil Abdo Shalabi. Beirut: Dar Alam Al-Kutub. 